\title{
THE RELATIONSHIPS BETWEEN TECHNOLOGICAL TURBULENCE, FLOW EXPERIENCE, INNOVATION PERFORMANCE AND SMALL FIRM GROWTH
}

\author{
Alenka SLAVEC GOMEZEL (i) ${ }^{1}$, Darija ALEKSIĆ (iD2* \\ ${ }^{1}$ Entrepreneurship, School of Economics and Business, University of Ljubljana, Ljubljana, Slovenia \\ ${ }^{2}$ Management and Organization, School of Economics and Business, University of Ljubljana, \\ Ljubljana, Slovenia
}

Received 18 Mach 2019; accepted 25 February 2020

\begin{abstract}
The main objective of the paper is to address the question of how to foster innovation and small firm growth under different levels of technological turbulence. Specifically, the paper examines the relationship among risk-taking, arising from different levels of technological turbulence, flow experience, innovation and small firm growth (i.e. market share and ROI growth). The underlying premise of our research is that there are substantial differences in low and high technological environments in terms of the relationships of risk taking, flow at work, innovation and small firm growth. Based on a survey among 188 entrepreneurs, the paper tests the proposed relationships in technological diverse environments with structural equation modelling. The results show that, when the level of technological turbulence is high, flow experience is significantly related to innovation and small firm growth, while in low-technological turbulence environment such relationships are not present. The study contributes to the entrepreneurial literature by demonstrating that in highly turbulent environments, flow experience may promote entrepreneurs' innovation and the efficiency of small firm performance. The study also provides new empirical insights about the relationship between entrepreneurs' behaviour, which is influenced by environmental conditions, on the one hand and innovation and small firm growth on the other hand.
\end{abstract}

Keywords: entrepreneur, flow, environment, technological turbulence, innovation, small firm growth, structural equation modelling.

JEL Classification: L26, L25, O31, D23.

\section{Introduction}

Innovation has been considered as a crucial source of competitive advantage in increasingly changing environments (Abdi et al., 2018). Gilsing, Vanhaverbekeargue, and Pieters (2014) argue that companies need to innovate and cooperate in order to capitalise on opportunities offered by technology and changing environments. However, companies are challenged by

${ }^{*}$ Corresponding author. E-mail: darija.aleksic@ef.uni-lj.si

This is an Open Access article distributed under the terms of the Creative Commons Attribution License (http://creativecommons. org/licenses/by/4.0/), which permits unrestricted use, distribution, and reproduction in any medium, provided the original author and source are credited. 
three factors: a) the uncertainty associated to the market opportunities that a new technology may cause, b) the ambiguity in transforming technological novelties into solutions that should meet customers' needs and c) the investment uncertainty of when and where to invest (Mullins \& Sutherland, 1998; Kashefi, 2016).

Uncertainty often arises from the amount of unpredictable changes in the environmental conditions. These environmental conditions are perceived and evaluated by entrepreneurs, thereby influencing their behavior (Gilinsky et al., 2019). In today's digital age, entrepreneurs operate in the environment, characterized by technological turbulence. Perceived technological turbulence refers to entrepreneurs' perception of whether the technology in their industry is changing rapidly, whether these changes are hard to forecast and whether these advancements present great opportunities for new product developments (Jaworski \& Kohli, 1993). Taking the perceived environmental uncertainty and turbulence lenses is an active research stream in entrepreneurship and technological forecasting research (de Jorge Moreno et al., 2010; Hu et al., 2018; Pratono et al., 2018; Roper \& Tapinos, 2016; Yasir et al., 2017), yet rarely actually implemented in empirical research (Knatko et al., 2016). Hence, our study contributes to the entrepreneurship and technological forecasting literature by conducting the empirical research among two groups of companies: the ones that perceive high technological turbulence and the ones that perceive low technological turbulence (Fernández et al., 2010) not necessarily related to the high-tech industry, since technological turbulence may be perceived also in other sectors (Bodlaj et al., 2012). Additionally, Hoffmann, Ramirez, and Lecamp (2018) argue that technological turbulence is not homogenous within the whole industry and that is experienced differently by different people, contingent on their "perceived adaptive capacity" to cope.

Over the past couple of decades several researches examined the influence of technological turbulence on company's performance. Most of them focused on the moderating effect of this phenomenon between two or more related constructs within organizations (for example new product development strategy planning (Calantone et al., 2003), organizational learning and firm innovativeness (Baba et al., 2017) and future trends coherence with company strategy in accelerated and turbulent environment (Battistella \& De Toni, 2011) or relationships among functional units (Fernández et al., 2010) as well as between interfirm networks (de Vaan, 2014; Hung \& Chou, 2013). However, less research has been done on the individual level that is in relation to the influence of technological uncertainty on the entrepreneurs' behaviour. Similarly, despite increasing recognition of innovation importance, studies that would show how to foster innovation are still relatively rare (Baer, 2012). Furthermore, little progress has been made in understanding how psychological factors affect innovation (Anderson et al., 2014).

In order to fill these knowledge gaps, this paper proposes the novel conceptualization and empirical investigation of the influence of technological turbulent environment on the entrepreneurs' behavior and psychological antecedents of performance (i.e. innovation, market share growth and ROI growth). Building on flow theory (Csikszentmihalyi, 1997), paper offers a new theoretical perspective on how to foster innovation, market share growth and ROI growth in low- and high-technological turbulent environments. Adding to our current knowledge, paper proposes that entrepreneurs, who often experience flow at work (i.e. 
"a psychological state in which the person feels simultaneously cognitively efficient, motivated, and happy" (Moneta \& Csikszentmihalyi, 1996, p. 277), will be more inclined to innovation (Baumann \& Scheffer, 2011). The flow state is a commonly reported phenomenon when individuals become deeply focused on a task and pursue it with such passion that all else disappears, including a sense of time or the worry of failure (Dietrich, 2004). Thus, paper proposes that flow experience may be an important factor that stimulates performance (i.e. innovation, market share growth and ROI growth).

The specific purpose of this study is to examine, the relationships between risk-taking, arising from the level of technological turbulence, flow experience and performance (i.e. innovation, market share and ROI growth) and to empirically examine proposed relationships in low- and high-technological turbulent environments. Our first intended contribution is to introduce the concept of flow experience into entrepreneurship literature and to address the call to provide more empirical evidences on how technological turbulence influences entrepreneurial behavior and performance (i.e. innovation, market share growth and ROI growth). Moreover, paper intends to contribute to innovation literature by examining the joint relationship between risk-taking, flow experience, and innovation in low- and high-technological turbulent environments. In addition, to the best of our knowledge, no research has empirically examined the relationship between flow experience and market share and ROI growth. Further, studies on how flow experience influences innovation are still relatively rare (Aleksić et al., 2016). Thus, paper also intends to make theoretical and empirical contributions to the flow experience literature by investigating how flow experience is related to innovation, market share and ROI growth in low- and high-technological turbulent environments.

Multi-group analysis revealed that flow experience is related to innovation and small firm growth in high-technological turbulent environment, while in low-technological turbulence environment such relationships are not present. Our results are consistent with the previous studies, indicating the effect of environmental turbulence and flow experience on firm performance (e.g., Baba et al., 2017; Baumann \& Scheffer, 2011; Aleksić et al., 2016). However, our study shows that psychological factors (i.e. flow experience) significantly affect firm performance only in high-technological turbulent environment.

The paper is structured as follows. After this Introduction, relevant literature is reviewed to build the hypotheses of the relationships between risk-taking, flow at work, innovation performance, market share growth and ROI growth. Next, methods and results of the study are presented, followed by the discussion, in which the contributions for theory and practice, future research opportunities and limitations of the study are highlighted. The paper with a Conclusion which summarizes the key findings of the study.

\section{Theory and hypotheses}

\subsection{Risk taking and flow experience}

Flow experience is defined as a state of intense engagement that is expected to be heightened when individuals see value in an activity and have clear goals, an appropriate balance between challenges and skills, and immediate feedback on actions and, thus, have some control over the outcome of the activity (Csikszentmihalyi, 1997). In order to experience flow, a 
balance between a high level of perceived challenges in a given situation and a high level of skills is required (Csikszentmihalyi, 1997). It is important to note that flow experience does not depend on an objective view of the posed challenges nor on an objective view of the skills an individual has (Chen et al., 1999), but it is determined by the individual's perceived state of how challenges and skills match each other (Csikszentmihalyi, 1975). In addition, Engeser and Rheinberg (2008) argued that the perceived importance of an activity plays an important role in determining the proper balance between challenges and skills, which leads to flow experience.

Technological turbulence is defined as the rate of change and instability of the technology environment (Jaworski \& Kohli, 1993). In a technological turbulent environment firms have to adapt to the technological changes within an industry which brings along risk-taking decisions, market haziness and risky investments (Calantone et al., 2003). Risk-taking is defined as individual's orientation toward taking chances in uncertain decision-making contexts (Koh, 1996). Brockhaus (1980) defined the propensity of risk taking as "the perceived probability of receiving the rewards associated with success of a proposed situation, which is required by an individual before he will subject himself to the consequences associated with failure, the alternative situation providing less reward as well as less severe consequences than the proposed situation" (p. 513). Risk-taking is positively related to firm performance and conditional to technological turbulence (Pratono, 2018). Individual risk-taking level is relatively inconsistent across situations, meaning that an individual may take risk in some circumstances, and avoid risk in other circumstances (Nicholson et al., 2005). Thus, it can be argued that the level of technological turbulence influences the perception of entrepreneur's risk taking.

In the low-technological turbulence environment technological changes are predictable and in such environments, entrepreneurs face relatively little uncertainty (Wu et al., 2005; Pratono et al., 2018). Thus, decision-making challenges are limited, and risk may be less obvious (Chen et al., 2015). Information processing requirements become minimal and they slowly increase or never reach the limit of entrepreneur's capabilities (Chen et al., 2015, 2012). Therefore, entrepreneurs will have proper capabilities to address the given challenges and will be able to experience higher levels of flow experience. In addition, when technological turbulence is low, decision variables are easily to identify and understood (Fredrickson, 1984). Further, entrepreneurs are likely to have the experience, necessary knowledge and skills to address the given challenges (Chen et al., 2015). Thus, it can be argued that in lowtechnological turbulent environment, entrepreneurs will perceive lower level of risk taking which will in turn have a positive effect on flow experience. Thus, the following hypothesis is proposed:

H1: Entrepreneurs' risk taking will be positively related to flow experience in the lowtechnological turbulence environment.

On the other hand, in the high-technological turbulence environment entrepreneurs are faced with rapidly changing technological environment, characterized by fast technological obsolescence (Zhao et al., 2014). High-technological turbulence environment may create opportunities for firms to build their superior competitive positions on one hand (Sheng et al., 2011), while it may also create challenges that lead to high failure rates on the other hand 
(Cunha et al., 2014). Namely, when technological turbulence is high, it is very difficult to make the right technological choice due the uncertainty and ambiguity that arise as a result of turbulence (Daft \& Weick, 1984). In order to remain competitive, entrepreneur's orientation toward taking chances in uncertain decision-making contexts (that is risk-taking) has to be high. In addition, in high-technological turbulence environment technology becomes more multi-disciplinary and dynamic (Zhao et al., 2014). Entrepreneurs have to have the ability to rapidly acquire diverse knowledge and provide new solutions to maintain competitive advantage (Cankurtaran et al., 2013; Wu et al., 2017). Providing new solutions is thus perceived as a highly important activity. If an activity is perceived as unimportant, with no further important consequences, the balance between challenges and skills should lead to flow experience, whereas for an activity with very important consequences, flow experience should only be experienced when skills exceed challenges (Engeser \& Rheinberg, 2008). However, high technological turbulence disrupts the balance between resource needs and available resources and skills (Atuahene-Gima \& Li, 2004). Entrepreneurs have to enhance their capabilities to deal with and to manage the risk under high environmental turbulence (Pratono, 2016). Thus, it can be argued that when technological turbulence is high, the balance between the given challenges and skills will be disturbed, thereby, entrepreneurs will experience lower level of flow experience at work. The following hypothesis is proposed:

$\mathrm{H} 2$ : Entrepreneurs' risk taking will be negatively related to flow experience in the hightechnological turbulence environment.

\subsection{Flow experience and innovation}

Innovation is defined as "generation, acceptance and implementation of new ideas, processes, products or services" (Thompson, 1965, p. 2). Once entrepreneurs have generated an idea, it is more likely that they will actually implement it, when an idea comes from an activity that they often perform, enjoy doing and that arouses their curiosity (Grant, 2008). According to Aleksić, Škerlavaj, and Dysvik (2016) flow experience stimulate individuals to actuality implement the idea, thereby stimulating innovation performance. When in flow, entrepreneurs become fully concentrated on the implementation of their goals, which encourages involvement in the implementation of activities and focus on relevant stimuli (Csikszentmihalyi, 1997). When in flow, entrepreneurs may perceive potential negative external factors (that is risk) caused by technological turbulence (low and high) as distraction. Namely, while experiencing flow, focus of awareness is narrowed down to the activity itself, everything else is forgotten and all distractions are excluded from consciousness (Chu \& Lan, 2010; Csikszentmihalyi, 1997) and individuals seek novelty and opportunities for action (Ceja \& Navarro, 2011).

Entrepreneurs, who often experience flow, see more opportunities in which they could get full involved and flow experience thus prompts a faster transition from the idea generation to its actual. They will be able to constantly seek challenges, be flexible, curious, and open to new possibilities, as well as enjoy experimenting with new ideas (Ceja \& Navarro, 2011; Csikszentmihalyi, 1997). Innovation process is usually accompanied by problems and challenges. When in flow, entrepreneurs will easier cope with challenges which may arise 
from innovation process (Aleksić et al., 2016). Namely, those engaged in flow activities may experience higher well-being (Collins et al., 2009) and those with a strong psychological wellbeing tend to have a higher level of positive attitude, which empowers them to solve problems and to handle crises situations smoothly (Zhang et al., 2015). When in flow, entrepreneurs will enjoy innovation process and experience higher levels of well-being, which will have a positive influence on innovation performance in (high and low) technological turbulence environment. Thus, the following hypotheses are proposed:

H3: Flow experience will be positively related to innovation performance of SMEs in the low-technological turbulence environment.

H4: Flow experience will be positively related to innovation performance of SMEs in the high-technological turbulence environment.

\subsection{Flow experience, market share and ROI growth}

Market share has been defined as "the number of units of the product type sold by the firm, compared with the number of units of the product type sold by all suppliers of that product" (Catry \& Chevalier, 1974, p. 43). Market share leaders are more profitable because they exploit economies of scale and market power, as well as reputational advantages (Armstrong \& Collopy, 1996). Sustaining industry leadership or closing the market share gap between themselves and the current leader are key organizational objectives for many firms (Ferrier et al., 1999). Therefore, managers usually have clearly in mind some market share objectives and they clearly define the actions required to attain these objectives (for example promotion, sales, pricing). Thereby, managers provide a target toward which employees should strive.

In order to experience flow, individuals have to have a clear understanding of what needs to be done, and although an activity may ultimately advance toward a higher goal, it is driven by the progressive realization of the next small goal (Csikszentmihalyi, 1997; Jackson \& Marsh, 1996). When experiencing flow, individuals focus their attention on a specific activity to the point of becoming totally absorbed in it. Entrepreneurs, who often experience flow at work, are strongly committed to the success of the business. Demerouti (2006) acknowledged that for goal-oriented and hardworking individuals flow experience has a strong influence on their in-role performance, because they will be focused on and immersed in the right things. In addition, flow experience increases determination and persistence in the activity being performed (Busch et al., 2013). Flow experience allows entrepreneurs to experience the sense of control over the given activity. Therefore, regardless of the level of technological turbulence, when in flow, entrepreneurs will be determined and persistent to achieve the set market share growth. Thus, the following hypotheses are proposed:

H5: Flow experience will be positively related to market share growth in the low-technological turbulence environment.

H6: Flow experience will be positively related to market share growth in the high-technological turbulence environment.

Further, market share and ROI growth are strongly related (Buzzell et al., 1975). In addition, investment decision process is based on a complex combination of demographics (that is age, gender, income), personal characteristics (personality traits, risk tolerance), markets 
(that is rate of return, transactional costs, market environment.), and related factors (Pak \& Mahmood, 2015). One might argue that flow experience (as one of the personal characteristics) is positively related to ROI growth.

In order to achieve high investment returns, entrepreneurs have to choose the proper strategy to position their firm to take advantage of opportunities and to effectively respond to competitive threats, manage costs and continually innovate to stay ahead of competition (Kaplan \& Norton, 2008). Thus, growth requires planning and a heavy dose of concentrated effort (Lyle et al., 1995). When in flow, individuals experience an absolute absorption in or a high degree of concentration on the activity due to undivided attention to a limited stimulus field (Bakker, 2008; Csikszentmihalyi, 1975; Engeser \& Rheinberg, 2008). Bakker (2008) found that flow experience facilitates concentration and dedication to work activities and, thereby, improve performance. ROI is widely regarded as the most useful measure and ultimate "bottom line" test of business performance (Reece \& Cool, 1978). Thus, it can be argued that, regardless of the level of technological turbulence, flow experience will have a positive influence on performance (that is ROI growth). Thus, the following hypotheses are proposed:

H7: Flow experience will be positively related to ROI growth in the low-technological turbulence environment.

H8: Flow experience will be positively related to ROI growth in the high-technological turbulence environment.

Figure 1 sums up our proposed theoretical model.

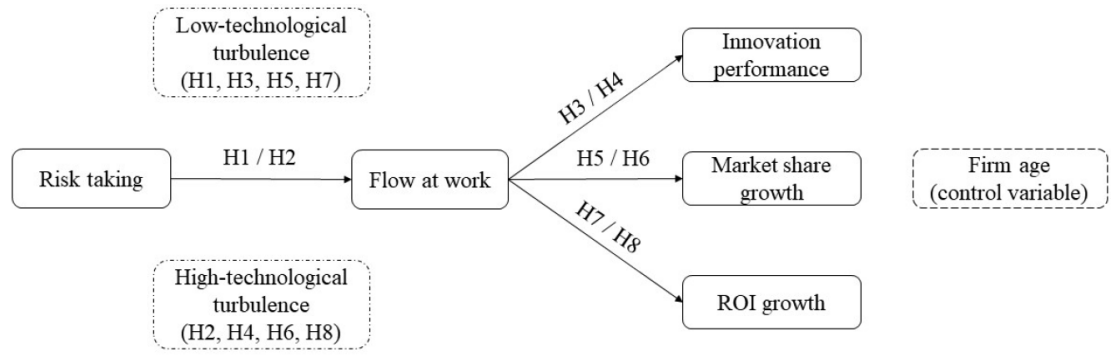

Figure 1. Summary of Hypotheses

\section{Methods}

\subsection{Research setting and data collection}

In February 2017, 3713 emails were sent to entrepreneurs, who were randomly selected from the national database of firms operating in Slovenia, the PIRS database. The sample was restricted to contain only small and medium sized companies to capture the entrepreneurs in smaller firms rather than managers of bigger firms. The entrepreneurs were contacted via e-mails and invited to participate in our web survey, which was administered through QuestioPro.com. QuestionPro sent emails with a cover letter and a link to the survey. The cover letter contained the information regarding the purpose of the study, the link to the online survey, the names and institutions of the researchers with the links to the online university profiles of researchers and an email and telephone contact for respondents, who wanted to 
ask us something. Motivation for why is it important to provide answers to the survey was provided and entrepreneurs were invited to share a contact if they were willing to receive the results of the study. After 2 reminders in February and March 2017 a total of 188 usable responses were received, that comprised the database for further analyses.

Slovenian sample, i.e. firms that are registered in Slovenia, was used to analyse how entrepreneurship and innovation management relate to risk taking and flow experience. Much research is predominantly done on US and UK samples, however understanding entrepreneurship and innovation in less developed and emerging economies is important if we want to know how to foster entrepreneurship activities and spur growth opportunities in such countries; especially so, if we consider that risk taking and flow experience have not been analysed before in connection with different levels of technological turbulence in a business environment.

The sample for statistical analysis consisted of 188 entrepreneurs, who were on average 50 years old, which means that also younger and older entrepreneurs participated in our study, had 25 years of experience, 72 percent were male and 28 percent were female, and their firms were on average 24 years old. The average age of firms is 23.7 years, they operate mainly in these sectors manufacturing (19\%), information and communication (13\%), construction (11\%), other business activities (11\%) and professional, scientific and technical activities (11\%). Other industries were represented in less than $10 \%$. The size of the firms is the following: $35 \%$ of firms are micro firms with up to 9 employees, $47 \%$ of firms are small firms with up to 49 employees, $15 \%$ of firms are medium-sized with up to 249 employees and $3 \%$ of firms are big firms with 250 employees and more. Similar samples' characteristics on studies of Slovenian entrepreneurs were evidenced by other scholars (Antončič, 2010; Global Entrepreneurhsip Monitor, 2016; Slavec et al., 2017).

\subsection{Measures}

Risk taking was measured with Venkataraman (1989) Riskiness dimension of the STROBE construct, which measures an overall pattern in decision-making of an entrepreneur. Respondents were asked to rate on a scale $1-5$ their agreement $(1=$ strongly disagree, $5=$ strongly agree) for the five items pertaining to the Riskiness dimension. One item ("My operations in business can be generally characterized as high risk") was excluded because of poor loading on the intended factor. The mean score on the 4-item measure of risk taking was 2.61 and Cronbach Alpha was 0.71 .

Flow experience was measured by The Work-Related Flow Inventory (WOLF), a measure developed and validated by Bakker (2008). Respondents were asked to indicate how often they experienced described situations in the last 14 days before the survey. The responses ranged from $1=$ never to 7 = always. The WOLF inventory consists of 13 items, of which 3 items were excluded because of poor loadings. The excluded items were "When I am working, I think about nothing else", "When I am working on something, I am doing it for myself" and "I am totally immersed in my work". The 1-factor measure of flow experience had a mean value of 5.49 and a Cronbach Alpha of 0.93 . 
Innovation was measured as a construct comprised by product and process innovations with a 6-item scale (Jiménez-Jiménez \& Sanz-Valle, 2011). Respondents were asked to indicate on a 7-point Likert scale how did their firm perform compared to competitors in the last three years in terms of innovation product and process activities, for example performance in regard to "the number of new products/services introduced". The anchors ranged from $1=$ Much worse than competitors to $5=$ Much better than competitors. The mean score on the 6-item measure of innovativeness was 3.56 and Cronbach Alpha was 0.89.

Market share increase or decrease in the last three years in comparison to competitors was measured by asking respondents to state on a scale ranged from $1=$ Much worse than competitors to $5=$ Much better than competitors the level of increase or decrease of their market share. The mean score of the market share growth was 3.38. In a similar vein, the increase or decrease of ROI compared to competitors in the last three years was measured. The mean value of the ROI increase or decrease compared to competitors was 3.36.

Finally, technological turbulence was measured with the scale developed by Jaworski and Kohli (1993). Respondents rated their agreement on a Likert scale ranging from $1=$ Strongly disagree to 5 = Strongly agree with the situations described by the measure's items. The mean value of the technological turbulence measure was 3.63 and Cronbach Alpha was 0.88 . To measure the differences of the structural models within low and high technological turbulence, the sample was divided in two parts and performed a multi-group analysis. Low technological turbulence was comprised by cases which reported an overall technological turbulence below 3.00, whereas all other cases were put in the group of high technological turbulence.

Several control variables, such as firm age, firm size, environmental dynamism, entrepreneurs' age, entrepreneurs' years of experience, and entrepreneurs' gender, were incorporated in the model. Only firm age was retained in the final model because this was the only control variable that had a statistically significant effect in the model. All other control variables did not have any statistically significant effect on the variables in the model. A table containing the final scales items, their factor loading is provided in the Appendix.

\subsection{Statistical analyses}

Exploratory factor analysis and reliability analysis were performed in IBM SPSS 19.0, whereas confirmatory factor analysis, convergent and discriminant validity, multi-group analysis with invariance analysis and structural equation modelling on the entire model under study was performed in AMOS 20.0.

\subsubsection{Convergent and discriminant validity tests}

Convergent and discriminant validity were assessed based on recommendations by Hair et al. (2010). To satisfy the criteria for convergent validity only the items of measurement scales that loaded considerably on the intendent factors, i.e. had factor loadings of 0.5 and above, were retained. The only exceptions were the riskiness item "New projects are approved on a "stage-by-stage" basis rather than with "blanket" approval" for both groups and the item of flow experience "When I am working, I forget everything else around me" for the high 
technological turbulence group, which loaded slightly below the suggested threshold. Those two items were retained to preserve the content domain of the constructs under study. Factor loadings of each item are reported in the Appendix.

Discriminant validity was assessed by comparing the squared roots of average variance extracted values for any two constructs (e.g. risk-taking and flow) with the correlation estimate between these two constructs. Since all squared roots of average variance extracted values were higher than the correlations with other constructs, it can be argued that the data displays discriminant validity. The squared roots of average variance-extracted values are reported on the diagonal of Table 2 and Table 3.

As show in Table 1, the fit of the model was adequate. For the measurement model, the fit statistics was the following: $\chi^{2}=641.53, \mathrm{DF}=426, \mathrm{p}=0.00, \mathrm{CFI}=0.91$, RMSEA $=0.05$, $\mathrm{GFI}=0.79, \mathrm{NFI}=0.79$, TLI $=0.90$. For the structural model, model fit statistics was the following: $\chi^{2}=669.82, \mathrm{DF}=436, \mathrm{p}=0.00, \mathrm{CFI}=0.91$, RMSEA $=0.05$, GFI $=0.78, \mathrm{NFI}=$ 0.78 , TLI $=0.89$. All in all, the results showed that dataset is robust to perform further analyses.

Table 1. Model fit statistics

\begin{tabular}{|l|c|c|c|c|c|c|c|c|}
\hline \multicolumn{1}{|c|}{ Model } & $\chi^{2}$ & DF & p-value & CF & RMSEA & GFI & NFI & TLI \\
\hline Measurement model & 641.53 & 426 & 0.00 & 0.91 & 0.05 & 0.79 & 0.79 & 0.90 \\
\hline Structural model & 669.82 & 436 & 0.00 & 0.91 & 0.05 & 0.78 & 0.78 & 0.89 \\
\hline
\end{tabular}

\subsubsection{Common method variance tests}

Common method variance was addressed in several ways. First, a pilot study on a smaller sample of entrepreneurs was conducted to test the clearness and soundness of instructions and responses. The results of pilot testing of the questionnaire showed that some instructions need to be reformulated. Second, respondents were assured confidentiality when answering the survey questions in order to reduce socially desirable responses (Podsakoff et al., 2003). Third, as suggested by Podsakoff, MacKenzie, and Podsakoff (2012) the common method factor analysis was performed. The common method factor analysis provided the information of a low average variance explained by the common method factor, i.e. 0.036, which is evidence of low threat of common method bias. Variance inflation factors (VIF) was also calculated to assess potential multicollinearity. VIFs were below the problematic threshold of 10, specifically the highest VIF was 1.835 , evidenced between flow experience and market share growth. Based on these tests it can be concluded that common method bias was not a threat to our data.

\subsubsection{Multi-group analysis}

Differences in the two groups - the low-technological turbulence group and high-technological turbulence group - was tested based on multi-group invariance analyses following suggestions by Byrne (2010). This represents an approximation of moderation analysis. For 
configural invariance, which is the initial step in multi-group invariance analysis, the only requirement is that the same number of factors and factor-loading patterns are specified across the groups. Here no equality constraints are imposed. The fit of the configural model represents the baseline for model comparisons in the next steps. In the second step, metric invariance is assessed. Here, factor loadings were constrained to be equal across groups and investigate the extent to which parameters in the measurement model are equivalent across groups. In the third step, scalar invariance in which we specify the equivalence of a causal structure in the structural model and test for factor covariance invariance and factor variance invariance were assessed. In each step, the change in model fit based on the change in CFI and $\chi^{2}$ were assessed.

\section{Results}

Table 2 shows the descriptive statistics and correlations among studied constructs for the low-technological turbulence group. Mean values and standard deviations for the constructs risk taking, flow experience, innovation performance, market share growth and ROI growth are reported. Correlations and p-values for the pairs of studied constructs and the squared roots of average variance extracted of the latent variables are also reported on the diagonal of the table.

Table 2. Correlations among constructs (low-technological turbulence)

\begin{tabular}{|l|c|c|c|c|c|c|c|}
\hline & Mean & SD & 1 & 2 & 3 & 4 & 5 \\
\hline 1. Risk taking & 2.571 & 0.572 & 0.738 & & & & \\
\hline $\begin{array}{l}\text { 2. Flow } \\
\text { experience }\end{array}$ & 5.432 & 1.047 & $\begin{array}{c}0.316 \\
\mathrm{p}=0.057\end{array}$ & 0.880 & & & \\
\hline $\begin{array}{l}\text { 3. Innovation } \\
\text { performance }\end{array}$ & 3.404 & 0.594 & $\begin{array}{c}0.365 \\
\mathrm{p}=0.037\end{array}$ & $\begin{array}{c}0.149 \\
\mathrm{p}=0.329\end{array}$ & 0.845 & & \\
\hline $\begin{array}{l}\text { 4. Market share } \\
\text { growth }\end{array}$ & 3.270 & 0.835 & $\begin{array}{c}0.001 \\
\mathrm{p}=0.995\end{array}$ & $\begin{array}{c}0.044 \\
\mathrm{p}=0.751\end{array}$ & $\begin{array}{c}0.657 \\
\mathrm{p}=0.001\end{array}$ & $/$ & \\
\hline 5. ROI growth & 3.233 & 0.846 & $\begin{array}{c}-0.173 \\
\mathrm{p}=0.256\end{array}$ & $\begin{array}{c}0.137 \\
\mathrm{p}=0.330\end{array}$ & $\begin{array}{c}0.647 \\
\mathrm{p}=0.001\end{array}$ & $\begin{array}{c}0.615 \\
\mathrm{p}=0.001\end{array}$ & $/$ \\
\hline 6. Firm age & 22.071 & 11.137 & $\begin{array}{c}-0.160 \\
\mathrm{p}=0.293\end{array}$ & $\begin{array}{c}-0.002 \\
\mathrm{p}=0.986\end{array}$ & $\begin{array}{c}0.164 \\
\mathrm{p}=0.268\end{array}$ & $\begin{array}{c}0.076 \\
\mathrm{p}=0.574\end{array}$ & $\begin{array}{c}0.160 \\
\mathrm{p}=0.241\end{array}$ \\
\hline
\end{tabular}

Table 3 shows the descriptive statistics and correlations among studied constructs for the high-technological turbulence. Mean values and standard deviations for the constructs risk taking, flow experience, innovation performance, market share growth and ROI growth are reported. Correlations and p-values for the pairs of studied constructs and the squared roots of average variance extracted of the latent variables are also reported on the diagonal of the table.

Figure 2 reports the results of structural equation modelling for the low-technological turbulence group. Hypotheses H1, H3, H5, and H7 described relationship in the low-technological turbulence group. 
Table 3. Correlations among constructs (high-technological turbulence)

\begin{tabular}{|l|c|c|c|c|c|c|c|}
\hline & Mean & SD & 1 & 2 & 3 & 4 & 5 \\
\hline 1. Risk taking & 2.633 & 0.629 & 0.793 & & & & \\
\hline $\begin{array}{l}\text { 2. Flow } \\
\text { experience }\end{array}$ & 5.515 & 0.937 & $\begin{array}{c}-0.020 \\
\mathrm{p}=0.843\end{array}$ & 0.865 & & & \\
\hline $\begin{array}{l}\text { 3. Innovation } \\
\text { performance }\end{array}$ & 3.626 & 0.636 & $\begin{array}{c}0.011 \\
\mathrm{p}=0.919\end{array}$ & $\begin{array}{c}0.324 \\
\mathrm{p}=0.002\end{array}$ & 0.860 & & \\
\hline $\begin{array}{l}\text { 4. Market } \\
\text { share growth }\end{array}$ & 3.425 & 0.803 & $\begin{array}{c}-0.105 \\
\mathrm{p}=0.296\end{array}$ & $\begin{array}{c}0.246 \\
\mathrm{p}=0.008\end{array}$ & $\begin{array}{c}0.603 \\
\mathrm{p}=0.001\end{array}$ & $/$ & \\
\hline 5. ROI growth & 3.407 & 0.802 & $\begin{array}{c}-0.050 \\
\mathrm{p}=0.616\end{array}$ & $\begin{array}{c}0.249 \\
\mathrm{p}=0.007\end{array}$ & $\begin{array}{c}0.569 \\
\mathrm{p}=0.001\end{array}$ & $\begin{array}{c}0.548 \\
\mathrm{p}=0.001\end{array}$ & $/$ \\
\hline 6. Firm age & 24.348 & 15.818 & $\begin{array}{c}-0.286 \\
\mathrm{p}=0.008\end{array}$ & $\begin{array}{c}-0.061 \\
\mathrm{p}=0.496\end{array}$ & $\begin{array}{c}0.080 \\
\mathrm{p}=0.363\end{array}$ & $\begin{array}{c}0.080 \\
\mathrm{p}=0.471\end{array}$ & $\begin{array}{c}-0.063 \\
\mathrm{p}=0.471\end{array}$ \\
\hline
\end{tabular}

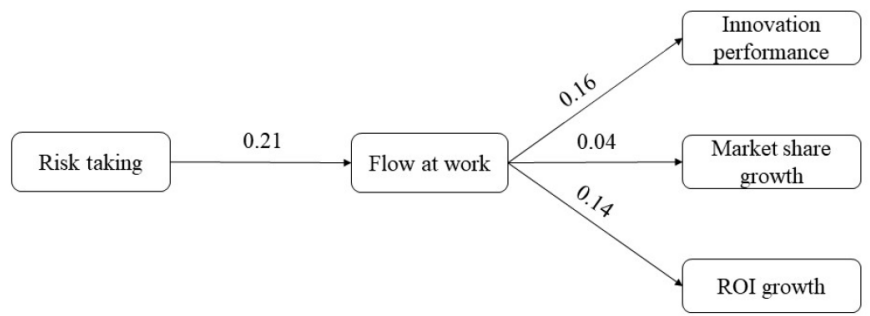

Figure 2. Results for model testing (low-technological turbulence)

Note: The dashed rectangle represents a control variable. ${ }^{\star} \mathrm{p}<0.05 ;{ }^{\star \star} \mathrm{p}<0.01 ;{ }^{\star \star \star} \mathrm{p}<0.001$.

Figure 3 reports the results of structural equation modelling for the high-technological turbulence group. Hypotheses H2, H4, H6, and H8 described relationship in the high-technological turbulence group.

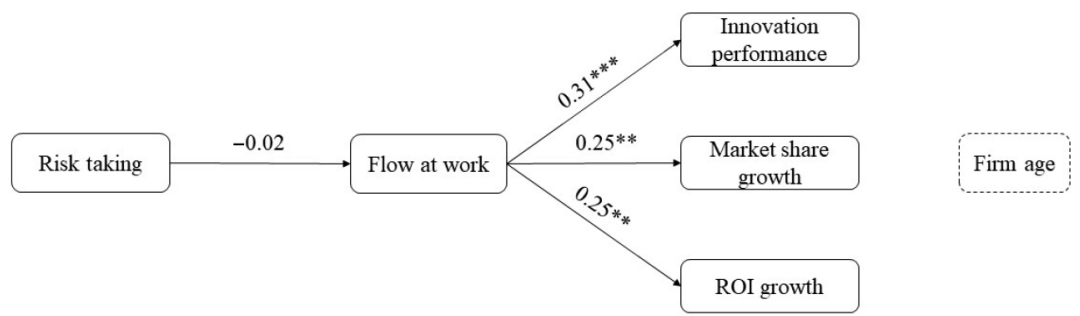

Figure 3. Results for model testing (high-technological turbulence)

Note: The dashed rectangle represents a control variable. ${ }^{\star} \mathrm{p}<0.05 ;{ }^{* *} \mathrm{p}<0.01 ;{ }^{* *} \mathrm{p}<0.001$.

$\mathrm{H} 1$ predicted that in the low-technological turbulence environment entrepreneurs' risk taking will be positively related to flow experience. The results show that risk taking is not statistically significantly related to flow experience $(r=0.21, p=0.22)$, therefore the first 
hypothesis was not confirmed. As depicted in Table 2 and 3, entrepreneurs reported lower levels of risk taking in low-technological turbulent environment than in high-technological turbulent environment. Based on results, it could be argued that when technological changes are predictable, entrepreneurs will less likely take actions that might have undesirable results (i.e. risky actions) and will more likely take conservative actions. The results also suggests that such actions are not perceived as challenging situations, which would stimulate flow experience. Paper also proposed and tested the potential positive consequences of flow experience (i.e. innovative performance, market share and ROI growth) in low-technological environment. $\mathrm{H} 3$, which predicted that in the low-technological turbulence environment flow experience work will be positively related to innovation performance of SMEs, was not confirmed either, since the regression coefficient was not statistically significant $(r=0.16$, $\mathrm{p}=0.28$ ). $\mathrm{H} 5$ and $\mathrm{H} 7$ predicted a positive relationship between flow experience and market share growth and ROI growth in the low-technological turbulence environment, but could not accept the hypotheses since there were no statistically significant regression coefficients (for H3: $\mathrm{r}=0.04, \mathrm{p}=0.75$, for H4: $\mathrm{r}=0.14, \mathrm{p}=0.32$ ).

For the high-technological turbulence environment the results were quite different since were able to confirm 3 hypotheses out of 4, namely $\mathrm{H} 4, \mathrm{H} 6$, and $\mathrm{H} 8$. $\mathrm{H} 2$ predicted a negative relationship between risk taking and flow experience in high-technological turbulence. However, the results demonstrated no statistically significant relationship $(\mathrm{r}=-0.02, \mathrm{p}=0.83)$. The results suggest that regardless of how technological turbulent environment is, risk taking is not related to flow experience. The positive relationship between flow experience and innovation performance of SMEs in high-technological turbulence environment (H4) was also analyzed. The results of model testing showed that there is a positive and significant relationship between flow experience and innovation performance $(\mathrm{r}=0.31, \mathrm{p}=0.001)$ and $\mathrm{H} 4$ was accepted. Finally, H6 and H8 predicted a positive relationship between flow experience and market share growth and ROI growth in the high-technological turbulence environment. The results of our study showed statistically significant regression coefficients (for $\mathrm{H} 7: \mathrm{r}=0.25$, $\mathrm{p}=0.004$, for H8: $\mathrm{r}=0.25, \mathrm{p}=0.005$ ), leading us to accept H6 and H8. Taken all together, the results suggest that in high technological turbulence environment, flow experience stimulates innovative performance, market share and ROI.

Additionally, the differences and similarities of the relationships among constructs in the theoretical model in terms of multi-group analysis was assessed. The results of multi-group invariance tests show that in both samples the measurement scales are represented with the same items, i.e. the measurement scales in both samples have the same structure, which confirms configural invariance of the structure. The results also confirmed metric invariance, in which factor loadings were constrained to be equal across the two groups. In both groups, the results showed the equivalence of factor loadings, since the change in CFI from the unconstrained model to the model with equality of factor loadings was small and below 0.01 (CFI drops from 0.907 to 0.904 ). The nested model comparisons showed that the $\Delta \chi^{2}>0.05$, i.e. is not significant, which is an additional sign of invariance. Finally, scalar invariance was tested. The results show that the invariance of structural weights, but no equivalence of structural covariances, which is in line with the results of separate model testing for each group and with the hypotheses, which predicted that some relationships among constructs will go in the 
opposite directions. Based on the nested model comparison, one can see that the $\Delta \chi 2>0.05$ (non-significant) for structural weights, whereas the $\Delta \chi^{2}<0.05$ (significant) for the structural covariances, meaning that the relationships between constructs are somewhat different in the two samples. The non-equivalence comes from the fact that in the low-technological turbulence group flow at work is not statistically significantly related to innovation performance, market share growth and ROI growth, whereas in the high-technological group the relationships between flow at work and innovation performance, market share growth and ROI growth are statistically significant and positive.

\section{Discussion and limitations}

This study has shed fresh light on the predictors of innovation and small firm growth in technological diverse environment. Paper builds on the assumption that the level of technological turbulence environment of the innovating company influences the level of uncertainty (Candi et al., 2013), which in turn, influences entrepreneurs' risk-taking perception (McCarthy et al., 2018). Further, drawing on flow theory, paper explains the relationships between risk taking perception and innovation. Specifically, it is theoretically proposed and empirically illustrated that flow experience seems to play an important role in idea implementation (that is innovation) in high-technological turbulent environments. Recent study showed that the impact of risk taking behaviour on performance is more effective at the low information technological turbulence (Pratono, 2018). However, empirical evidence presented in the present study suggest that flow experience may mitigate the negative consequences of high technological turbulence and thereby enable effective performance also at high technological turbulence. In addition, paper proposed and found support for our sixth and eighth hypotheses by demonstrating the positive relationship between flow experience and market share and ROI growth in high-technological turbulence environments. Multi-group analysis, which is an approximation of moderation analysis was also performed. The results of the tests show that there are substantial differences in the two group (i.e. low- and high-technological turbulent environment groups) in terms of the relationships of flow at work and outcome variables (innovation performance, market share growth and ROI growth). The results are consistent with the previous studies, indicating the moderating effect of environmental turbulence on firm performance (e.g., Baba et al., 2017).

Several important implications arise from the study with respect to understating entrepreneurs' behaviour and innovation in high-technological turbulence environments. First, paper contributes to the entrepreneurship literature by addressing the need to examine the relationships between environmental factors and entrepreneurial behaviour, experience and performance (Gilinsky et al., 2019). Further, Knatko, Shirokova, and Bogatyreva (2016) argued that perceived environmental turbulence is rarely empirical examined in the entrepreneurship literature. Thus, paper also contributes to the entrepreneurship literature by providing empirical evidences, showing how perceived technological turbulence influences entrepreneurs' risk taking. Second, the study contributes to the innovation literature by responding to the call to explore the influence of psychological factors on innovation (Anderson et al., 2014; Maqbool et al., 2019). Namely, to the best of our knowledge, this is the first study that provides concep- 
tualization and empirical examination of the influence of flow experience (i.e. psychological factor) on innovation in the entrepreneurship research. Paper proposed and find the support that those entrepreneurs, who work in high-technological turbulent environments and who often experience flow at work, are more likely to enjoy experimenting new ideas, which may in turn increase their innovation. The study is in line with studies that postulated that flow experience prompts a faster transition from intention to actual implementation of novel idea (Baumann \& Scheffer, 2011; Aleksić et al., 2016). The findings of the study suggest that in order to increase innovation actions, entrepreneurs should experience high levels of flow. In addition, paper also contributes to the innovation theory by providing empirical evidence that technological turbulence alters the impact on innovation. Specifically, the results suggest that flow experience increases innovation in certain environment (that is high-technological turbulence environments). Firms can maximize their performance by adjusting their strategy and structure to the environment (Miller \& Friesen, 1982), thus adopting less centralized and more organic structures when operating in dynamic and volatile environments (Calantone et al., 2003). However, the study suggests that entrepreneurs, who often experience flow experience, are more comfortable making decisions in unpredictable environments and are more likely to propose new, innovative solutions.

Third, the research takes a step further towards flow experience in the work setting and thereby suggests several contributions for flow theory. Paper contributes to the flow theory by empirically examine the role of flow experience in innovation. To the best of our knowledge, this is the first study that empirically examines the influence of flow experience on innovation among entrepreneurs. In addition, this is also one of the rare studies that introduces the flow theory into the field of innovation and entrepreneurship (for example Aleksić et al., 2016). To experience flow, individuals must recognize a challenge or opportunity for action; therefore, they must be flexible, open to new possibilities, seek out novelty, and be curious, experimental, and adaptable (Ceja \& Navarro, 2011; Csikszentmihalyi, 1997). The study suggests that when technological turbulence is high, entrepreneurs should experience high level of flow in order to be innovative. In addition, an important theoretical contribution of this paper is the conceptualization of the relationship between flow, market share and ROI growth. The results suggest the positive association between flow experience and market share and ROI growth in high-technological turbulence environments. The results are congruent with the previous research, showing that flow experience stimulates positive, organizationally relevant outcomes such as creativity, performance, learning (Debus et al., 2014). However, the link between flow and organizational performance (i.e. market share and ROI growth) is novel. Paper therefore contributes an important piece of theoretical conceptualization and empirical research on flow consequences on organizational level.

As with any research, there are some limitations of this study to be noted. First, since the research focuses on the entrepreneurs' perception of technological turbulence, risk taking and flow experience, self-report data with a questionnaire were collected. It could be argued that the study suffers from common method bias. However, the common method bias was decreased with procedural and statistical remedies as reported in the paper and common method bias was not a threat in the data. Still, we leave the chance that results are biased to some extent. 
Second, the data is cross-sectional, and it does not account for potential reverse causality among variables. A longitudinal approach to the research might reveal different patterns among variables, but attention should be made to introduce a proper time lag (Spector, 2019). However, the theoretical foundations of the proposed directions of relationships were carefully reviewed to be sure to propose sound hypotheses. Keeping this in mind, future research could build upon the results of the present study and applies a longitudinal perspective.

Finally, the study did not directly test the relationship between specific dimensions of flow, innovation, market share and ROI growth. Future research in exploring the relationship between specific dimension of flow, innovation, market share and ROI growth can deepen our understanding of proposed relationships and is therefore required. In addition, despite the comprehensive model of entrepreneurs' perception variables on the personal level, it is certain there are important variables that were left out of the model and should be considered in future research. For example, additional empirical investigations are needed in order to obtain a deeper understanding of the relationship between flow experience, market share and ROI growth. Future research can also investigate the relationship between flow and internationalization activities of small firms, since entrepreneurs in the study evidenced an inclination to being comfortable in unpredictable environments when in flow. One aspect of unpredictable environment is also a foreign market, so export activities of entrepreneurs might be also considered (Ruzzier \& Konecnik Ruzzier, 2014), also in connection to innovation and growth (Fuertes-Callén \& Cuellar-Fernández, 2019).

Limitations notwithstanding, the research provides an expanded perspective of flow experience outcomes contingent on the external forces from the environment and supports the important role of flow experience in firm performance (that is innovation, market share and ROI growth).

\section{Conclusions}

The purpose of the study was to examine the relationships between risk-taking, flow experience and performance (i.e. innovation, market share and ROI growth) and to empirically examine proposed relationships in low- and high-technological turbulence environments. The results suggest that regardless of how technological turbulent environment is, risk taking is not related to flow experience. Further, the results suggest that in low-technological turbulence environment innovative performance, market share and ROI are not driven by flow experience. It seems that in stable environment (i.e. low-technological turbulence environment), entrepreneurs will less likely find the proper balance between their skills and challenges, needed to experience flow. Therefore, they will less likely experience flow, which, in turn, decreases the prevalence of flow-related positive consequences. However, the findings of the study suggest that when the level of technological turbulence is high, flow experience stimulates performance. Since flow theory emphasizes the role of context and posits that flow experience varies depending on the meaning of a situation to the individual, one could argue that entrepreneurs perceive challenges arising from high-technological turbulence environments as meaningful. Consequently, entrepreneurs experience higher levels of flow, which stimulates innovative performance, market share and ROI. 


\section{Acknowledgements}

The authors acknowledge the financial support from the Slovenian Research Agency (research core funding No. P5-0410).

We would like to express our great appreciation to Dr. Kaja Rangus for her valuable contributions during the planning and initial development of this research work.

\section{Funding}

This research did not receive any specific grant from funding agencies in the public, commercial, or not-for-profit sectors.

\section{Author contributions}

ASG, DA and KR conceived the study. DA and KR were responsible for the theoretical development of the paper. ASG and KR were responsible for data collection, ASG was responsible for data analysis and data interpretations. DA was responsible for developing study's implications.

\section{Disclosure statement}

There is no conflict of interest to report.

\section{References}

Abdi, K., Mardani, A., Senin, A., Tupenaite, L., Naimaviciene, J., Kanapeckiene, L., \& Kutut, V. (2018). The effect of knowledge management, organizational culture and organizational learning on innovation in automotive industry. Journal of Business Economics and Management, 19(1), 1-19. https://doi.org/10.3846/jbem.2018.1477

Aleksić, D., Škerlavaj, M., \& Dysvik, A. (2016). The flow of creativity for idea implementation. In M. Škerlavaj, M. Černe, A. Dysvik, \& A. Carlsen (Eds.), Capitalizing on creativity at work: Fostering the implementation of creative ideas in organizations (pp. 29-38). Edward Elgar Publishing. https://doi.org/10.4337/9781783476503

Anderson, N., Potočnik, K., \& Zhou, J. (2014). Innovation and creativity in organizations: A stateof-the-science review, prospective commentary, and guiding framework. Journal of Management, 40(5), 1297-1333. https://doi.org/10.1177/0149206314527128

Antončič, B. (2010). The entrepreneur's general personality traits and technological developments. International Journal of Human and Social Sciences, 5(12), 785-790.

Armstrong, J. S., \& Collopy, F. (1996). Competitor orientation: Effects of objectives and information on managerial decisions and profitability. Journal of Marketing Research, 33(2), 188-199. https://doi.org/10.1177/002224379603300206

Atuahene-Gima, K., \& Li, H. (2004). Strategic decision comprehensiveness and new product development outcomes in new technology ventures. Academy of Management Journal, 47(4), 583-597. https://doi.org/10.5465/20159603 
Baba, M., Mahmood, R., \& Halipah, A. (2017). The moderating role of environmental turbulence on the relationship between organizational learning and firm innovativeness. International Journal of Management Research \& Review, 7(2), 148-159.

Baer, M. (2012). Putting creativity to work: The implementation of creative ideas in organizations. Academy of Management Journal, 55(5), 1102-1119. https://doi.org/10.5465/amj.2009.0470

Bakker, A. B. (2008). The work-related flow inventory: Construction and initial validation of the WOLF. Journal of Vocational Behavior, 72(3), 400-414. https://doi.org/10.1016/j.jvb.2007.11.007

Battistella, C., \& De Toni, A. F. (2011). A methodology of technological foresight: A proposal and field study. Technological Forecasting and Social Change, 78(6), 1029-1048.

https://doi.org/10.1016/j.techfore.2011.01.006

Baumann, N., \& Scheffer, D. (2011). Seeking flow in the achievement domain: The achievement flow motive behind flow experience. Motivation and Emotion, 35(3), 267-284.

https://doi.org/10.1007/s11031-010-9195-4

Bodlaj, M., Coenders, G., \& Žabkar, V. (2012). Responsive and proactive market orientation and innovation success under market and technological turbulence. Journal of Business Economics and Management, 13(4), 666-687. https://doi.org/10.3846/16111699.2011.620143

Brockhaus, R. H. (1980). Risk taking propensity of entrepreneurs. Academy of Management Journal, 23(3), 509-520. https://doi.org/10.2307/255515

Busch, H., Hofer, J., Chasiotis, A., \& Campos, D. (2013). The achievement flow motive as an element of the autotelic personality: Predicting educational attainment in three cultures. European Journal of Psychology of Education, 28(2), 239-254. https://doi.org/10.2307/255515

Buzzell, R. D., Gale, B. T., \& Sultan, R. G. (1975). Market share-a key to profitability. Harvard Business Review, 53(1), 97-106.

Byrne, B. M. (2010). Structural equation modeling for AMOS: Basic concepts, applications, and programming ( $2^{\text {nd }}$ ed.). Routledge.

Calantone, R., Garcia, R., \& Dröge, C. (2003). The effects of environmental turbulence on new product development strategy planning. Journal of Product Innovation Management, 20(2), 90-103. https://doi.org/10.1111/1540-5885.2002003

Candi, M., van den Ende, J., \& Gemser, G. (2013). Organizing innovation projects under technological turbulence. Technovation, 33(4-5), 133-141. https://doi.org/10.1016/j.technovation.2013.01.002

Cankurtaran, P., Langerak, F., \& Griffin, A. (2013). Consequences of new product development speed: A meta-analysis. Journal of Product Innovation Management, 30(3), 465-486.

https://doi.org/10.1111/jpim.12011

Catry, B., \& Chevalier, M. (1974). Market share strategy and the product life cycle: The competitive value of market share for a product varies with its stage in the product life cycle. Journal of Marketing, 38(4), 29-34. https://doi.org/10.1177/002224297403800405

Ceja, L., \& Navarro, J. (2011). Dynamic patterns of flow in the workplace: Characterizing within-individual variability using a complexity science approach. Journal of Organizational Behavior, 32(4), 627-651. https://doi.org/10.1002/job.747

Chen, H., Wigand, R. T., \& Nilan, M. S. (1999). Optimal experience of web activities. Computers in Human Behavior, 15(5), 585-608. https://doi.org/10.1016/S0747-5632(99)00038-2

Chen, J., Neubaum, D. O., Reilly, R. R., \& Lynn, G. S. (2015). The relationship between team autonomy and new product development performance under different levels of technological turbulence. Journal of Operations Management, 33, 83-96. https://doi.org/10.1016/j.jom.2014.10.001

Chen, J., Reilly, R. R., \& Lynn, G. S. (2012). New product development speed: too much of a good thing? Journal of Product Innovation Management, 29(2), 288-303.

https://doi.org/10.1111/j.1540-5885.2011.00896.x 
Chu, L.-C., \& Lan, C.-H. (2010). Relationship between job characteristics and flow experience of R\&D personnel: Case study of A High Technology Company in Taiwan. Journal of Global Business Management, 6(1), 1-10.

Collins, A. L., Sarkisian, N., \& Winner, E. (2009). Flow and happiness in later life: An investigation into the role of daily and weekly flow experiences. Journal of Happiness Studies, 10(6), 703-719. https://doi.org/10.1007/s10902-008-9116-3

Csikszentmihalyi, M. (1975). Beyond boredom and anxiety. Jossey-Bass.

Csikszentmihalyi, M. (1997). Finding flow: The psychology of engagement with everyday life. HarperCollins Publishers.

Cunha, M. P. e, Rego, A., Oliveira, P., Rosado, P., \& Habib, N. (2014). Product innovation in resourcepoor environments: Three research streams. Journal of Product Innovation Management, 31(2), 202-210. https://doi.org/10.1111/jpim.12090

Daft, R. L., \& Weick, K. E. (1984). Toward a model of organizations as interpretation systems. Academy of Management Review, 9(2), 284-295. https://doi.org/10.5465/amr.1984.4277657

de Jorge Moreno, J., Laborda Castillo, L., \& de Zuani Masere, E. (2010). Firm size and entrepreneurial characteristics: Evidence from the SME sector in Argentina. Journal of Business Economics and Management, 11(2), 259-282. https://doi.org/10.3846/jbem.2010.13

de Vaan, M. (2014). Interfirm networks in periods of technological turbulence and stability. Research Policy, 43(10), 1666-1680. https://doi.org/10.1016/j.respol.2014.07.007

Debus, M. E., Sonnentag, S., Deutsch, W., \& Nussbeck, F. W. (2014). Making flow happen: The effects of being recovered on work-related flow between and within days. Journal of Applied Psychology, 99(4), 713-722. https://doi.org/10.1037/a0035881

Demerouti, E. (2006). Job characteristics, flow, and performance: The moderating role of conscientiousness. Journal of Occupational Health Psychology, 11(3), 266-280.

https://doi.org/10.1037/1076-8998.11.3.266

Dietrich, A. (2004). Neurocognitive mechanisms underlying the experience of flow. Consciousness and Cognition, 13(4), 746-761. https://doi.org/10.1016/j.concog.2004.07.002

Engeser, S., \& Rheinberg, F. (2008). Flow, performance and moderators of challenge-skill balance. Motivation and Emotion, 32(3), 158-172. https://doi.org/10.1007/s11031-008-9102-4

Fernández, P., Del Río, M. L., Varela, J., \& Bande, B. (2010). Relationships among functional units and new product performance: The moderating effect of technological turbulence. Technovation, 30(5-6), 310-321. https://doi.org/10.1016/j.technovation.2009.09.003

Ferrier, W. J., Smith, K. G., \& Grimm, C. M. (1999). The role of competitive action in market share erosion and industry dethronement: A study of industry leaders and challengers. Academy of Management Journal, 42(4), 372-388. https://doi.org/10.2307/257009

Fredrickson, J. W. (1984). The comprehensiveness of strategic decision processes: Extension, observations, future directions. Academy of Management Journal, 27(3), 445-466. https://doi.org/10.5465/256039

Fuertes-Callén, Y., \& Cuellar-Fernández, B. (2019). Inter-relationship between firm growth and profitability in a context of economic crisis. Journal of Business Economics and Management, 20(1), 86-106. https://doi.org/10.3846/jbem.2019.6928

Gilinsky, A., Eyler, R., Newton, S., \& A. Downing, J. (2019). Environmental perceptions on entrepreneurial thinking in the wine industry. Small Enterprise Research, 26(1), 105-116. https://doi.org/10.1080/13215906.2019.1570319

Gilsing, V., Vanhaverbeke, W., \& Pieters, M. (2014). Mind the gap: Balancing alliance network and technology portfolios during periods of technological uncertainty. Technological Forecasting and Social Change, 81, 351-362. https://doi.org/10.1016/j.techfore.2013.04.010 
Global Entrepreneurship Monitor. (2016). 2015/2016 Global Report. Global Entrepreneurship Research Association, London.

Grant, A. M. (2008). Does intrinsic motivation fuel the prosocial fire? Motivational synergy in predicting persistence, performance, and productivity. Journal of Applied Psychology, 93(1), 48-58. https://doi.org/10.1037/0021-9010.93.1.48

Hair, J. F., Black, W. C., Babin, B. J., \& Anderson, R. E. (2010). Multivariate data analysis (7 ${ }^{\text {th }}$ ed.). Prentice-Hall.

Hoffmann, J., Ramirez, R., \& Lecamp, L. (2018). Right on time - Socioecological strategy and implications of turbulence in the Swiss watchmaking field. Technological Forecasting and Social Change, 137, 101-117. https://doi.org/10.1016/j.techfore.2018.06.047

Hu, L., Gu, J., Wu, J., \& Lado, A. A. (2018). Regulatory focus, environmental turbulence, and entrepreneur improvisation. International Entrepreneurship and Management Journal, 14(1), 129-148. https://doi.org/10.1007/s11365-017-0446-7

Hung, K.-P., \& Chou, C. (2013). The impact of open innovation on firm performance: The moderating effects of internal R\&D and environmental turbulence. Technovation, 33(10-11), 368-380. https://doi.org/10.1016/j.technovation.2013.06.006

Jackson, S. A., \& Marsh, H. W. (1996). Development and validation of a scale to measure optimal experience: The Flow State Scale. Journal of Sport and Exercise Psychology, 18(1), 17-35. https://doi.org/10.1123/jsep.18.1.17

Jaworski, B. J., \& Kohli, A. K. (1993). Market orientation: Antecedents and consequences. Journal of Marketing, 57(3), 53-70. https://doi.org/10.1177/002224299305700304

Jiménez-Jiménez, D., \& Sanz-Valle, R. (2011). Innovation, organizational learning, and performance. Journal of Business Research, 64(4), 408-417. https://doi.org/10.1016/j.jbusres.2010.09.010

Kaplan, R. S., \& Norton, D. P. (2008). The execution premium: Linking strategy to operations for competitive advantage. Harvard Business Press.

Kashefi, M. A. (2016). Effect of salvage market on strategic technology choice and capacity investment decision of firm under demand uncertainty. Journal of Business Economics and Management, 17(1), 140-155. https://doi.org/10.3846/16111699.2012.734325

Knatko, D., Shirokova, G., \& Bogatyreva, K. (2016). Industry choice by young entrepreneurs in different country settings: The role of human and financial capital. Journal of Business Economics and Management, 17(4), 613-627. https://doi.org/10.3846/16111699.2015.1113199

Koh, H. C. (1996). Testing hypotheses of entrepreneurial characteristics: A study of Hong Kong MBA students. Journal of Managerial Psychology, 11(3), 12-25. https://doi.org/10.1108/02683949610113566

Lyle, M., Baird, I., Orris, B., \& Kuratko, D. (1995). Formalized planning in small business: Increasing strategic choice. Journal of Small Business Management, 33(1), 38-50.

Maqbool, S., Černe, M., \& Bortoluzzi, G. (2019). Micro-foundations of innovation: Employee silence, perceived time pressure, flow and innovative work behaviour. European Journal of Innovation Management, 22(1), 125-145. https://doi.org/10.1108/EJIM-01-2018-0013

McCarthy, D. J., Puffer, S. M., \& Lamin, A. (2018). Entrepreneurial orientation in a hostile and turbulent environment: Risk and innovativeness among successful Russian entrepreneurs. European Journal of International Management, 12(1-2), 191-221. https://doi.org/10.1504/EJIM.2018.089033

Miller, D., \& Friesen, P. H. (1982). Innovation in conservative and entrepreneurial firms: Two models of strategic momentum. Strategic Management Journal, 3(1), 1-25.

https://doi.org/10.1002/smj.4250030102

Moneta, G. B., \& Csikszentmihalyi, M. (1996). The effect of perceived challenges and skills on the quality of subjective experience. Journal of Personality, 64(2), 275-310.

https://doi.org/10.1111/j.1467-6494.1996.tb00512.x 
Mullins, J. W., \& Sutherland, D. J. (1998). New product development in rapidly changing markets: An exploratory study. Journal of Product Innovation Management, 15(3), 224-236. https://doi.org/10.1111/1540-5885.1530224

Nicholson, N., Soane, E., Fenton-O’Creevy, M., \& Willman, P. (2005). Personality and domain-specific risk taking. Journal of Risk Research, 8(2), 157-176. https://doi.org/10.1080/1366987032000123856

Pak, O., \& Mahmood, M. (2015). Impact of personality on risk tolerance and investment decisions: A study on potential investors of Kazakhstan. International Journal of Commerce and Management, 25(4), 370-384. https://doi.org/10.1108/IJCoMA-01-2013-0002

Podsakoff, P. M., MacKenzie, S. B., \& Podsakoff, N. P. (2012). Sources of method bias in social science research and recommendations on how to control it. Annual Review of Psychology, 63(1), 539-569. https://doi.org/10.1146/annurev-psych-120710-100452

Podsakoff, P. M., MacKenzie, S. B., Lee, J.-Y., \& Podsakoff, N. P. (2003). Common method biases in behavioral research: A critical review of the literature and recommended remedies. Journal of Applied Psychology, 88(5), 879-903. https://doi.org/10.1037/0021-9010.88.5.879

Pratono, A. H. (2016). Strategic orientation and information technological turbulence: Contingency perspective in SMEs. Business Process Management Journal, 22(2), 368-382.

https://doi.org/10.1108/BPMJ-05-2015-0066

Pratono, A. H. (2018). Does firm performance increase with risk-taking behavior under information technological turbulence? Empirical evidence from Indonesian SMEs. The Journal of Risk Finance, 19(4), 361-378. https://doi.org/10.1108/JRF-10-2017-0170

Pratono, A. H., Ratih, R. V. S., \& Arshad, D. (2018). Does entrepreneurial autonomy foster SME growth under technological turbulence? The empirical evidence from Indonesia. Journal of Technology in Behavioral Science, 3(3), 170-178. https://doi.org/10.1007/s41347-018-0051-9

Reece, S. J., \& Cool, R. W. (1978). Measuring investment center performance. Harvard Business Review, $56,28-46$.

Roper, S., \& Tapinos, E. (2016). Taking risks in the face of uncertainty: An exploratory analysis of green innovation. Technological Forecasting and Social Change, 112, 357-363.

https://doi.org/10.1016/j.techfore.2016.07.037

Ruzzier, M., \& Konecnik Ruzzier, M. (2014). On the relationship between firm size, resources, age at entry and internationalization: The case of Slovenian SMEs. Journal of Business Economics and Management, 16(1), 52-73. https://doi.org/10.3846/16111699.2012.745812

Sheng, S., Zhou, K. Z., \& Li, J. J. (2011). The effects of business and political ties on firm performance: Evidence from China. Journal of Marketing, 75(1), 1-15. https://doi.org/10.1509/jm.75.1.1

Slavec, A., Drnovšek, M., \& Hisrich, R. D. (2017). Entrepreneurial openness: Concept development and measure validation. European Management Journal, 35(2), 211-223.

https://doi.org/10.1016/j.emj.2016.09.003

Spector, P. E. (2019). Do not cross me: Optimizing the use of cross-sectional designs. Journal of Business and Psychology, 34(2), 125-137. https://doi.org/10.1007/s10869-018-09613-8

Thompson, V. A. (1965). Bureaucracy and innovation. Administrative Science Quarterly, 1, 1-20. https://doi.org/10.2307/2391646

Venkataraman, S. (1989). Strategic orientation of business enterprises: The construct, dimensionality, and measurement. Management Science, 35(8), 942-962. https://doi.org/10.1287/mnsc.35.8.942

Wu, K. J., Tseng, M. L., Chiu, A. S., \& Lim, M. K. (2017). Achieving competitive advantage through supply chain agility under uncertainty: A novel multi-criteria decision-making structure. International Journal of Production Economics, 190, 96-107. https://doi.org/10.1016/j.ijpe.2016.08.027

Wu, S., Levitas, E., \& Priem, R. L. (2005). CEO tenure and company invention under differing levels of technological dynamism. Academy of Management Journal, 48(5), 859-873.

https://doi.org/10.5465/amj.2005.18803927 
Yasir, M., Majid, A., \& Yasir, M. (2017). Entrepreneurial knowledge and start-up behavior in a turbulent environment. Journal of Management Development, 36(9), 1149-1159. https://doi.org/10.1108/JMD-10-2016-0193

Zhang, P., Wang, D. D., \& Owen, C. L. (2015). A study of entrepreneurial intention of university students. Entrepreneurship Research Journal, 5(1), 61-82. https://doi.org/10.1515/erj-2014-0004

Zhao, Y., Cavusgil, E., \& Cavusgil, S. T. (2014). An investigation of the black-box supplier integration in new product development. Journal of Business Research, 67(6), 1058-1064.

https://doi.org/10.1016/j.jbusres.2013.06.006

\section{APPENDIX}

\section{Final scales' items and standardised loadings (based on the CFA)}

\begin{tabular}{|l|l|c|}
\hline \multicolumn{1}{|c|}{ Scales and items } & \multicolumn{2}{c|}{$\begin{array}{l}\text { Loading } \\
\text { Low tech / High tech }\end{array}$} \\
\hline $\begin{array}{l}\text { RISKINESS (Venkataraman, 1989) } \\
\text { (Strongly disagree/Strongly agree) }\end{array}$ & \multicolumn{2}{|l|}{} \\
\hline $\begin{array}{l}\text { I seem to adopt a rather conservative view when making major decisions } \\
\text { (R). }\end{array}$ & 0.713 & 0.618 \\
\hline $\begin{array}{l}\text { I have a tendency to support projects for which the expected returns are } \\
\text { certain (R). }\end{array}$ & 0.600 & 0.767 \\
\hline My approach has generally followed the "tried and true" paths (R). & 0.690 & 0.767 \\
\hline $\begin{array}{l}\text { New projects are approved on a "stage-by-stage" basis rather than with } \\
\text { "blanket" approval (R). }\end{array}$ & 0.329 & 0.364 \\
\hline $\begin{array}{l}\text { FLOW EXPERIENCE (Bakker, 2008) } \\
\text { (Never/Always) }\end{array}$ & & \\
\hline I feel happy during my work. & 0.725 & 0.854 \\
\hline I get carried away by my work. & 0.815 & 0.648 \\
\hline When I am working, I forget everything else around me. & 0.530 & 0.491 \\
\hline I get my motivation from the work itself, and not from the reward for it. & 0.723 & 0.612 \\
\hline I feel cheerful when I am working. & 0.832 & 0.854 \\
\hline I would still do this work, even if I received less pay. & 0.688 & 0.650 \\
\hline I find that I also want to work in my free time. & 0.788 & 0.669 \\
\hline I work because I enjoy it. & 0.904 & 0.888 \\
\hline My work gives me a good feeling. & 0.877 & 0.906 \\
\hline I do my work with a lot of enjoyment. & 0.863 & 0.912 \\
\hline $\begin{array}{l}\text { INNOVATION (Jiménez-Jiménez \& Sanz-Valle, 2011) } \\
\text { (Much worse than competitors/Much better than competitors) }\end{array}$ & 0.801 & 0.693 \\
\hline $\begin{array}{l}\text { In the last 3 years, our firm has performed worse/better than competitors } \\
\text { in regard to the number of new products/services launched. }\end{array}$ & & 0.714 \\
\hline $\begin{array}{l}\text { In the last 3 years, our firm has performed worse/better than competitors } \\
\text { in regard to pioneering the introduction of new products/services (you } \\
\text { were one of the first to introduce a new product/service). }\end{array}$ & 0.715 \\
\hline
\end{tabular}




\begin{tabular}{|c|c|c|}
\hline Scales and items & \multicolumn{2}{|c|}{$\begin{array}{l}\text { Loading } \\
\text { Low tech / High tech }\end{array}$} \\
\hline $\begin{array}{l}\text { In the last } 3 \text { years, our firm has performed worse/better than competitors } \\
\text { in regard to the effort invested in the development of new products/ } \\
\text { services, taking into consideration the number of hours, people, teams } \\
\text { and trainings. }\end{array}$ & 0.840 & 0.885 \\
\hline $\begin{array}{l}\text { In the last } 3 \text { years, our firm has performed worse/better than competitors } \\
\text { in regard to the number of introduced changes in processes. }\end{array}$ & 0.637 & 0.768 \\
\hline $\begin{array}{l}\text { In the last } 3 \text { years, our firm has performed worse/better than competitors } \\
\text { in regard to pioneering newly introduced processes (you've been one of } \\
\text { the first to introduce new processes). }\end{array}$ & 0.704 & 0.763 \\
\hline $\begin{array}{l}\text { In the last } 3 \text { years, our firm has performed worse/better than competitors } \\
\text { in regard to responding to new processes introduced by other companies } \\
\text { in your field. }\end{array}$ & 0.536 & 0.602 \\
\hline \multicolumn{3}{|l|}{$\begin{array}{l}\text { MARKET SHARE GROWTH } \\
\text { (Much worse than competitors/Much better than competitors) }\end{array}$} \\
\hline $\begin{array}{l}\text { Please, rate the increase or decrease of market share of your company in } \\
\text { the last three years. }\end{array}$ & l & l \\
\hline \multicolumn{3}{|l|}{$\begin{array}{l}\text { RETURN ON INVESTEMENT GROWTH } \\
\text { (Much worse than competitors/Much better than competitors) }\end{array}$} \\
\hline $\begin{array}{l}\text { Please, rate the increase or decrease of return on investment of your } \\
\text { company in the last three years. }\end{array}$ & l & l \\
\hline \multicolumn{3}{|l|}{$\begin{array}{l}\text { TECHNOLOGICAL TURBULENCE* (Jaworski \& Kohli, 1993) } \\
\text { (Strongly disagree/ Strongly agree) }\end{array}$} \\
\hline The technology in our industry is changing rapidly. & \multicolumn{2}{|c|}{0.727} \\
\hline Technological changes provide big opportunities in our industry. & \multicolumn{2}{|c|}{0.898} \\
\hline $\begin{array}{l}\text { A large number of new product ideas have been made possible through } \\
\text { technological breakthroughs in our industry. }\end{array}$ & \multicolumn{2}{|c|}{0.943} \\
\hline Technological developments in our industry are rather minor. (R) & \multicolumn{2}{|c|}{0.620} \\
\hline
\end{tabular}

Note: Technological turbulence items' loadings are presented for the entire database. 